\title{
Analysis of Glycoproteins Produced by the Associated Gland in the Olfactory Organ of Lungfish
}

\author{
Nobuaki NAKAMUTA ${ }^{1,2)}$, Shoko NAKAMUTA ${ }^{1,2)}$, Kazumi TANIGUCHI ${ }^{3)}$ and Kazuyuki TANIGUCHI ${ }^{1,2) *}$ \\ 1) Laboratory of Veterinary Anatomy, Faculty of Agriculture, Iwate University, Morioka, Iwate 020-8550, Japan \\ ${ }^{2)}$ United Graduate School of Veterinary Sciences, Gifu University, Gifu 501-1193, Japan \\ ${ }^{3)}$ Laboratory of Veterinary Anatomy, School of Veterinary Medicine, Kitasato University, Towada, Aomori 034-8628, Japan
}

(Received 18 December 2012/Accepted 10 February 2013/Published online in J-STAGE 22 February 2013)

ABSTRACT. The olfactory organ of African lungfish, Protopterus annectens, contains two distinct sensory epithelia: the lamellar olfactory epithelium and the recess epithelium. These epithelia correspond to the olfactory epithelium and the vomeronasal organ of tetrapods, respectively. In contrast to the lamellar olfactory epithelium, which has no associated gland, the recess epithelium is equipped with associated glands. Although the glandular cells and/or the supporting cells are generally presumed to secrete proteins involved in the function of olfactory sensory epithelia, the properties of these proteins in lungfish have not been evaluated to date. In this study, we investigated the associated glands in the olfactory organ of lungfish by transmission electron microscopy and found that the glandular cells contain numerous secretory granules and secrete them from the apical membrane. In addition, we analyzed the olfactory organ by lectin histochemistry using 16 biotinylated lectins. All lectins labeled the secretory granules in the glandular cells with different staining patterns from those of the supporting cells in the lamellar olfactory epithelium or in the recess epithelium. Furthermore, lectin blotting analysis showed that multiple bands were detected by the lectins which specifically labeled the glandular epithelium of the olfactory organ. These results indicate that the secretory products of the associated glands in the recess epithelium have different properties from those of the supporting cells in the olfactory sensory epithelia and contain multiple glycoproteins with different carbohydrate moieties.

KEY WORDS: electron microscopy, fish, glycoprotein, vomeronasal organ.

doi: 10.1292/jvms.12-0547; J. Vet. Med. Sci. 75(7): 887-893, 2013

Many vertebrates have two distinct olfactory organs, the olfactory epithelium (OE) and the vomeronasal organ (VNO) for detecting chemical substances in the environment. Unlike the OE found in all vertebrates, it has been suggested that the $\mathrm{VNO}$ is not present in fish, but is present only in terrestrial vertebrates [4]. However, the lungfish, phylogenetically the closest fish to tetrapods, have epithelial crypts that express VNO markers of tetrapods [10]. Recently, we have examined the olfactory organ of African lungfish, Protopterus annectens, and revealed the histological and ultrastructural characteristics of the lamellar OE and the recess epithelium, corresponding to the $\mathrm{OE}$ of ordinary fish and the VNO of tetrapods, respectively [19]. These two sensory epithelia are separately distributed in the olfactory organ of lungfish: the lamellar OE is located on the surface of olfactory lamellae and the recess epithelium in recesses at the base of lamellae [19].

In all vertebrates, olfactory receptors detect chemical substances dissolved in the mucous fluid covering the sensory epithelium $[8,20]$. The OE and the VNO of terrestrial vertebrates are equipped with the associated glands: the Bowman's glands in the OE and the Jacobson's glands in the VNO $[3,4,15]$. Since the associated glands are absent in the

*Correspondence to: Taniguchi, K., Laboratory of Veterinary Anatomy, Faculty of Agriculture, Iwate University, 3-18-8 Ueda, Morioka, Iwate 020-8550, Japan.

e-mail: anatomia@iwate-u.ac.jp

(C)2013 The Japanese Society of Veterinary Science olfactory organ of ordinary fish [8], their presence in lungfish can be considered to be exceptional. These glands are associated with the recess epithelium, but not with the lamellar OE in lungfish: by examining serial sections of the olfactory organ, we confirmed that the recess epithelium is equipped with the glandular epithelium in virtually all recesses (our unpublished data). In spite of their possible importance in the function of the recess epithelium, the properties of these glands have never been investigated.

Lectins have been used to identify and localize different glycoconjugates expressed in many types of cells [22, 24]. Lectins are proteins that specifically bind to the terminal sugar residues on complex carbohydrates. To date, the olfactory system of a variety of vertebrates, from fish to mammals, has been analyzed by lectin histochemistry [2, 5, 7, 14, 16-18, 21, 23, 26]. Binding patterns for lectins in the secretory granules of glandular cells are different between the $\mathrm{OE}$ and the VNO $[2,5,7,16,26]$.

In this study, we investigated both the ultrastructural characteristics and sugar residues of the associated glands in the olfactory organ of lungfish with transmission electron microscopy and by lectin histochemistry using 16 types of lectins, respectively. Moreover, we analyzed the proteins extracted from the lungfish olfactory organ by lectin blotting, using several lectins which exclusively labeled the secretory granules of the glandular cells. Our results indicate that the secretory granules of glandular cells have distinct properties from those of the supporting cells in the two sensory epithelia and contain multiple glycoproteins with different carbohydrate moieties. 
Table 1. Carbohydrate binding specificities of lectins

\begin{tabular}{|c|c|c|c|c|}
\hline Lectin & Abbreviation & Concentration $(\mathrm{mg} / \mathrm{m} l)^{*}$ & Binding specificity & Inhibitory sugar \\
\hline Wheat germ agglutinin & WGA & $5.0 \times 10^{-2}$ & $\beta$-GlcNAc & Chitin Hydrolysate \\
\hline Succinylated wheat germ agglutinin & s-WGA & $2.0 \times 10^{-2}$ & $\beta$-GlcNAc & Chitin Hydrolysate \\
\hline Lycopersicon esculentum lectin & LEL & $4.0 \times 10^{-3}\left(4.0 \times 10^{-3}\right)$ & $\beta$-GlcNAc & Chitin Hydrolysate \\
\hline Solanum tuberosum lectin & STL & $1.0 \times 10^{-2}$ & $\beta$-GlcNAc & Chitin Hydrolysate \\
\hline Bandeiraea simplicifolia lectin-II & BSL-II & $1.0 \times 10^{-2}$ & $\alpha, \beta-G l c N A c$ & Chitin Hydrolysate \\
\hline Bandeiraea simplicifolia lectin-I & BSL-I & $4.0 \times 10^{-3}\left(2.0 \times 10^{-3}\right)$ & $\alpha$-GalNAc $>\alpha$-Gal & $0.2 \mathrm{M} \mathrm{Gal}+0.2 \mathrm{M} \mathrm{GalNAc}$ \\
\hline Vicia villosa agglutinin & VVA & $1.0 \times 10^{-2}$ & $\alpha, \beta$-GalNAc & $0.2 \mathrm{M}$ GalNAc \\
\hline Soybean agglutinin & SBA & $1.0 \times 10^{-2}$ & $\alpha, \beta-G a l N A c$, Gal & $0.2 \mathrm{M}$ GalNAc \\
\hline Sophora japonica agglutinin & SJA & $2.0 \times 10^{-2}\left(5.0 \times 10^{-2}\right)$ & $\beta$-GalNAc, $\beta$-Gal & $0.2 \mathrm{M}$ GalNAc \\
\hline Jacalin & Jaca & $1.0 \times 10^{-2}\left(4.0 \times 10^{-3}\right)$ & galactosyl- $\beta$-GalNAc & $0.8 \mathrm{M} \mathrm{Gal}$ \\
\hline Peanut agglutinin & PNA & $5.0 \times 10^{-2}\left(5.0 \times 10^{-2}\right)$ & galactosyl- $\beta$-GalNAc & $0.2 \mathrm{M} \mathrm{Gal}$ \\
\hline Erythrina cristagalli lectin & ECL & $5.0 \times 10^{-2}\left(5.0 \times 10^{-2}\right)$ & galactosyl- $\beta$-GlcNAc & $0.2 \mathrm{M} \mathrm{Lac}$ \\
\hline Ulex europaeus agglutinin-I & UEA-I & $5.0 \times 10^{-2}$ & $\alpha$-Fuc & $0.2 \mathrm{M} \mathrm{L}-$ Fuc \\
\hline Concanavalin A & Con A & $2.0 \times 10^{-3}$ & $\alpha$-Man & $0.2 \mathrm{M} \alpha-\mathrm{MG}+0.2 \mathrm{M} \alpha-\mathrm{MM}$ \\
\hline Pisum satibum agglutinin & PSA & $5.0 \times 10^{-2}$ & $\alpha$-Man & $0.2 \mathrm{M} \alpha-\mathrm{MG}+0.2 \mathrm{M} \alpha-\mathrm{MM}$ \\
\hline Lens culinaris agglutinin & LCA & $5.0 \times 10^{-2}$ & $\alpha$-Man & $0.2 \mathrm{M} \alpha-\mathrm{MG}+0.2 \mathrm{M} \alpha-\mathrm{MM}$ \\
\hline
\end{tabular}

Fuc: fucose, Gal: galactose, GalNAc: N-acetylgalactosamine, GlcNAc: N-acetylglucosamine, Man: mannose, MG: methyl glucose, MM: methyl mannoside, *: For lectin blotting, lectins were used at concentrations given in parentheses.

\section{MATERIALS AND METHODS}

Animals: Seven juvenile or adult African lungfish $P$. annectens, approximately $30 \mathrm{~cm}$ in length, were purchased from commercial suppliers. All procedures were in accordance with the Principles for Animal Experiments of Iwate University. In all cases, the fish were anesthetized with ice and euthanized by decapitation.

Electron microscopy: The nasal sac was dissected out from one fish, cut into small pieces and fixed in $2 \%$ glutaraldehyde plus $2.5 \%$ paraformaldehyde in $0.1 \mathrm{M}$ cacodylate buffer ( $\mathrm{pH}$ 7.4) overnight at $4^{\circ} \mathrm{C}$. Specimens were postfixed in $1 \%$ osmium tetroxide for $2 \mathrm{hr}$ at $4^{\circ} \mathrm{C}$, dehydrated in a graded series of ethanol, substituted with propylene oxide and embedded in epoxy resin. Ultrathin sections were cut with a diamond knife, stained with uranyl acetate and lead citrate, and examined with a transmission electron microscope JEM-2100 (JEOL, Tokyo, Japan).

Lectin histochemistry: The nasal sac was dissected out from four fish and fixed in Bouin's solution at $4^{\circ} \mathrm{C}$ for $24 \mathrm{hr}$. The specimens were routinely embedded in paraffin and cut sagittally at $5 \mu \mathrm{m}$ in thickness. Sections were either stained with hematoxylin-eosin (HE) for histological examination or processed for lectin histochemistry as described below. Lectin histochemistry with 16 biotinylated lectins (Vector Laboratories, Burlingame, CA, U.S.A.; as shown in Table 1) was carried out using the avidin-biotin peroxidase complex method with a Vectastain ABC kit (Vector Laboratories). After deparaffinization, the sections were incubated in $0.3 \%$ $\mathrm{H}_{2} \mathrm{O}_{2}$ in methanol, at room temperature (RT) for $30 \mathrm{~min}$, to inactivate endogenous peroxidase and then incubated with $1 \%$ bovine serum albumin in phosphate-buffered saline $(\mathrm{pH}$ 7.4) (PBS) at $37^{\circ} \mathrm{C}$ for $30 \mathrm{~min}$ to block non-specific binding. The sections were then incubated with one of the biotinylated lectins at $4^{\circ} \mathrm{C}$ overnight or at RT for $2 \mathrm{hr}$, followed by Vectastain $\mathrm{ABC}$ reagent at $37^{\circ} \mathrm{C}$ for $30 \mathrm{~min}$. The sections were colorized with $0.05 \mathrm{M}$ Tris- $\mathrm{HCl}$ buffer ( $\mathrm{pH}$ 7.6) containing $0.01 \%$ 3-3' diaminobenzidine tetrahydrochloride (DAB) and $0.003 \% \mathrm{H}_{2} \mathrm{O}_{2}$ at $37^{\circ} \mathrm{C}$ for $15 \mathrm{~min}$. Between each step, the sections were rinsed in PBS for three times, 5 min each. Finally, the sections were counterstained with methyl green. Negative controls for the lectin histochemistry included (1) omission of lectin from the medium and (2) preincubation of the lectins with the appropriate competing sugars (Vector Laboratories; see Table 1) at RT for $1 \mathrm{hr}$. Concentration and sugar specificity of lectins are listed in Table 1. The optimal concentration for each lectin was determined by preliminary experiments to obtain high-contrast and low-background images.

Lectin blotting: The nasal sac was dissected out from two fish and homogenized in the RIPA buffer (Nacalai tesque, Kyoto, Japan) containing $50 \mathrm{mM}$ Tris- $\mathrm{HCl}$ buffer ( $\mathrm{pH}$ 7.6), $150 \mathrm{mM} \mathrm{NaCl}, 1 \%$ Nonidet P40, $0.5 \%$ sodium deoxy cholate, protease inhibitor cocktail and $0.1 \%$ sodium dodecyl sulfate (SDS). Lysates were obtained by centrifugation at $10,000 \times \mathrm{g}$ for $10 \mathrm{~min}$. The lysates were added to equal amount of EzApply (Atto, Tokyo, Japan) containing 100 mM Tris- $\mathrm{HCl}$ buffer ( $\mathrm{pH} 8.8$ ), $2 \%$ SDS, $20 \%$ sucrose, $0.06 \%$ bromophenol blue and $100 \mathrm{mM}$ dithiothreitol, heat-treated at $99^{\circ} \mathrm{C}$ for $5 \mathrm{~min}$ and then electrophoresed on either $7.5 \%$ or $10 \%$ polyacrylamide gel. The separated proteins were transferred to a polyvinylidene difluoride membrane. For staining the total proteins, the membrane was incubated with a Coomassie Brilliant Blue staining solution, CBB Stain One (Nacalai tesque) at RT for $30 \mathrm{~min}$ and washed in distilled water. Lectin blotting was performed with 6 lectins: Jaca, SJA, PNA, ECL, BSL-I and LEL (Table 1). After blocking with Tris-buffered saline (TBS) containing 10\% EzBlock (Atto) and $0.1 \%$ polysorbate at RT for $30 \mathrm{~min}$, the membrane was incubated with one of the lectins at RT for $2 \mathrm{hr}$. After washing in TBS containing $0.1 \%$ polysorbate (TBST), the membrane was incubated with Vectastain $\mathrm{ABC}$ reagent 


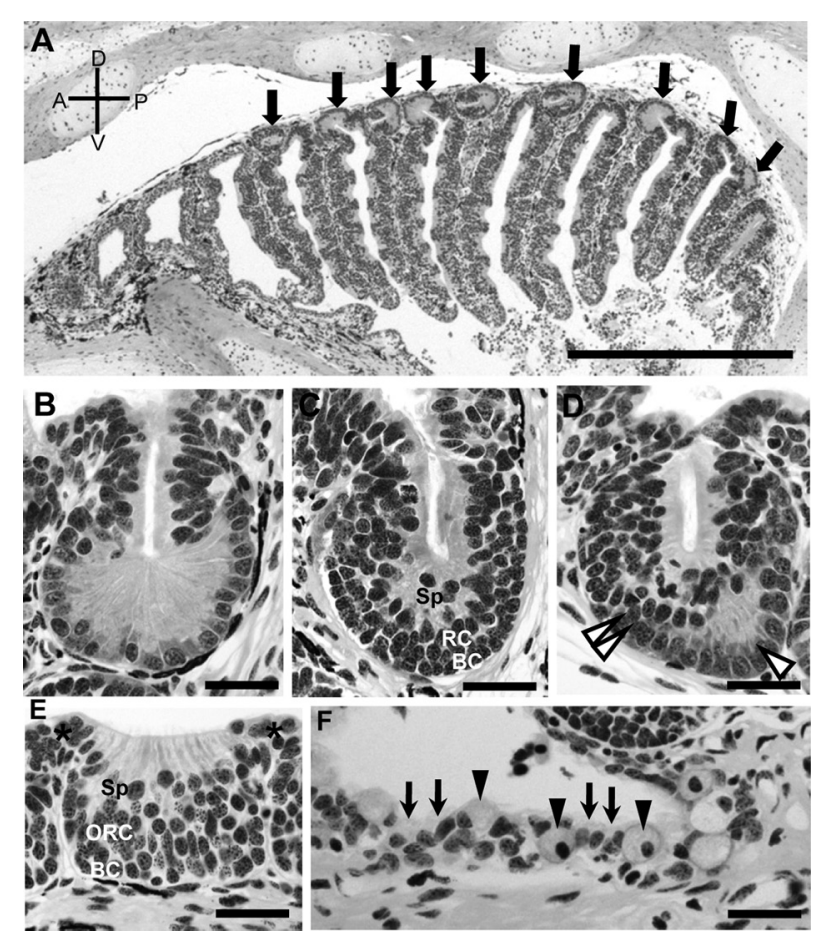

Fig. 1. The olfactory organ of lungfish stained with HE. (A) Lower magnification view. Dorsal is top, and anterior is left. The recesses (arrows) are observed at the base of lamellae hanging from the dorsal wall of the nasal sac. The recess is lined with the glandular epithelium (B) or the recess epithelium (C). The recess epithelium consists of supporting cells (Sp), receptor cells (RC) and basal cells (BC). (D) Both the glandular epithelium (arrowhead) and the recess epithelium (double arrowhead) are contained in a single recess. (E) The lamellar olfactory epithelium consists of the Sp, olfactory receptor cells (ORC) and BC. Neighboring lamellar olfactory epithelia are separated by non-sensory epithelium (asterisks). (F) The wall of the nasal sac is covered with the respiratory epithelium containing the cuboidal cells (arrows) and the goblet cells (arrowheads). Scale bars $=1 \mathrm{~mm}$ in (A), $50 \mu \mathrm{m}$ in (B-F).

at RT for $1 \mathrm{hr}$. After washing in TBST, the membrane was incubated with $0.05 \mathrm{M}$ Tris- $\mathrm{HCl}$ buffer ( $\mathrm{pH}$ 7.6) containing $0.01 \%$ DAB and $0.003 \% \mathrm{H}_{2} \mathrm{O}_{2}$ at RT for between 5 and 10 min to detect positive signals. For negative controls of lectin blotting, lectins were pre-incubated with the appropriate competing sugars (Vector Laboratories; Table 1) at RT for $1 \mathrm{hr}$.

\section{RESULTS}

Structure of the lungfish olfactory organ: A number of lamellae are bound to the ceiling with a connecting portion, resulting in that they looked like the lamellae were hanging from the ceiling. At the base of lamellae connecting the lamellae and the dorsal ceiling, recesses with a diameter of 100-200 $\mu \mathrm{m}$ were observed (Fig. 1A). The recesses were lined with either the glandular epithelium or the recess epithelium (Fig. 1B-D). The glandular epithelium was consti-

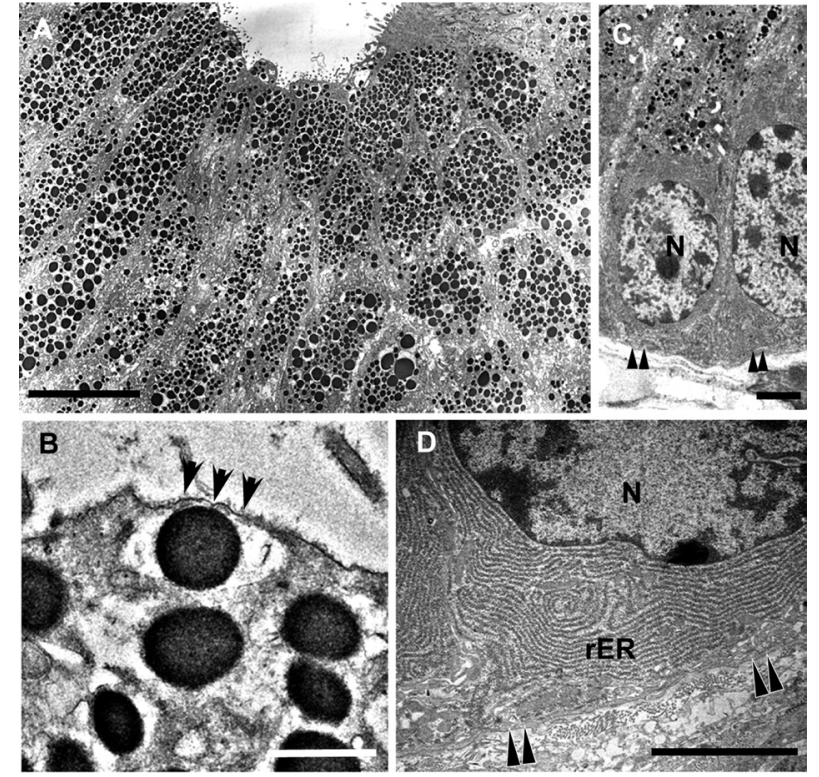

Fig. 2. Ultrastructure of the glandular epithelium. (A) Apical part of the glandular epithelium. A few microvilli are observed on the free border. The cytoplasm is filled with numerous electron-dense secretory granules. (B) High magnification view of the free border. A granule is likely to be discharged from the free border by exocytosis (arrows). (C) Basal part of the glandular epithelium. Double arrowheads indicate the basal membrane. Round to oval nuclei $(\mathrm{N})$ are situated basally. Secretory granules can be seen in the supranuclear region, but not in the perinuclear cytoplasm. (D) Higher magnification view of the basal region. Double arrowheads indicate the basal membrane. Well-developed rough endoplasmic reticula (rER) fill the perinuclear cytoplasm. Scale bars $=10 \mu \mathrm{m}$ in (A), $1 \mu \mathrm{m}$ in (B), $5 \mu \mathrm{m}$ in (C and D).

tuted of cylindrical cells with a basally-located round nucleus and eosinophilic cytoplasm (Fig. 1B). The recess epithelium consisted of the supporting cells, receptor cells and basal cells (Fig. 1C). Nuclei of the supporting cells were located in the upper half, nuclei of the receptor cells in the lower half and nuclei of the basal cells just above the basal membrane. Some recesses were lined with both the glandular epithelium and the recess epithelium (Fig. 1D). The surface of lamellae was covered with either the lamellar OE or the non-sensory epithelium (Fig. 1E). The lamellar OE consisted of the supporting cells, olfactory receptor cells and basal cells. Wall of the nasal sac was covered with the respiratory epithelium containing cuboidal cells and goblet cells (Fig. 1F).

Ultrastructure of the associated glands: The ultrastructure of the glandular epithelium was investigated by transmission electron microscopy (Fig. 2). The glandular cells possessed microvilli on the apical surface and numerous electrondense secretory granules in the supranuclear cytoplasm (Fig. 2A). The granules appeared to be discharged from the free border by exocytosis (Fig. 2B). Secretory granules were not observed in the basal portion of the glandular cells (Fig. 2C); instead, the basal cytoplasm, as well as the perinuclear cy- 
Table 2. Lectin binding in the olfactory organ of lungfish

\begin{tabular}{|c|c|c|c|c|c|c|c|}
\hline \multirow{2}{*}{ Lectin } & \multirow{2}{*}{$\begin{array}{l}\text { Glandular } \\
\text { epithelium }\end{array}$} & \multicolumn{2}{|c|}{ Lamellar olfactory epithelium } & \multicolumn{2}{|c|}{ Recess epithelium } & \multicolumn{2}{|c|}{ Respiratory epithelium } \\
\hline & & Supporting cells & Receptor cells & Supporting cells & Receptor cells & Cuboidal cells & Goblet cells \\
\hline WGA & ++ & $+/-$ & $+/-$ & ++ & + & ++ & $+/-$ \\
\hline s-WGA & ++ & - & - & - & - & $-\sim+*$ & ++ \\
\hline LEL & ++ & + & ++ & + & ++ & - & - \\
\hline STL & ++ & $+/-$ & $+/-$ & + & + & - & - \\
\hline BSL-II & + & - & - & - & - & ++ & ++ \\
\hline BSL-I & ++ & $+/-$ & - & + & + & - & - \\
\hline VVA & ++ & $+/-$ & $+/-$ & ++ & - & $+/-$ & $+/-$ \\
\hline SBA & ++ & $+/-$ & - & $+/-$ & - & - & - \\
\hline SJA & + & - & - & $+/-$ & - & - & - \\
\hline Jaca & + & - & - & - & - & - & - \\
\hline PNA & $-\sim++*$ & - & - & - & - & - & $+/-$ \\
\hline ECL & ++ & - & - & - & - & - & - \\
\hline UEA-I & ++ & - & - & $+/-$ & - & + & ++ \\
\hline Con A & + & $+/-$ & + & $+/-$ & ++ & + & - \\
\hline PSA & + & $+/-$ & - & - & - & - & - \\
\hline LCA & ++ & $+/-$ & ++ & $+/-$ & ++ & $+/-$ & - \\
\hline
\end{tabular}

++ intense staining; + moderate staining; +/- weak staining; - no staining.

*: Staining intensity varies from cell to cell.

toplasm, was filled with well-developed rough endoplasmic reticula (rER) (Fig. 2D).

Lectin histochemistry: The lectin binding patterns in the olfactory organs are summarized in Table 2. The cytoplasm of the glandular cells was stained with all 16 lectins. Staining for these lectins was punctate (Fig. 3A-F). Both Jaca and SJA moderately stained the glandular cells (Fig. 3A,B). Staining intensity for PNA varied from cell to cell in the glandular epithelium: some cells were intensely stained, while others were not (Fig. 3C). ECL, BSL-I and LEL intensely stained the glandular cells (Fig. 3D-F). In the lamellar OE, the supporting cells and the olfactory receptor cells were stained with 8 lectins and 6 lectins, respectively. On the other hand, the supporting cells and the receptor cells were stained with 9 lectins and 6 lectins, respectively, in the recess epithelium. The staining intensities of supporting cells with 7 lectins (WGA, STL, BSL-I, VVA, SJA, UEA-I and PSA) were different between the lamellar $\mathrm{OE}$ and the recess epithelium. Different staining intensities with the 14 lectins (except for WGA and VVA) were observed between the supporting cells in the recess epithelium and the glandular cells. In the respiratory epithelium, the cuboidal cells and the goblet cells were stained with 7 lectins and 6 lectins, respectively. Four lectins (Jaca, SJA, PNA and ECL) almost exclusively stained the glandular epithelium in the olfactory organ. ECL did not stain the lamellar OE, the recess epithelium and the respiratory epithelium (Fig. 3D'-D'"). BSL-I weakly stained the cytoplasm of supporting cells in the lamellar OE (Fig. 3E'), and moderately stained the supporting cells and the receptor cells in the recess epithelium (Fig. 3E"), but did not stain the respiratory epithelium (Fig. 3E"'). LEL moderately stained the supporting cells and intensely stained the receptor cells both in the lamellar OE (Fig. 3F') and the recess epithelium (Fig. 3F"), but did not stain the respiratory epithelium (Fig. $\left.3 F^{\prime \prime}\right)$. No positive reactions were observed in the negative controls in which lectins were omitted or pre-incubated with the appropriate competing sugars in the cases of all 16 lectins (data not shown).

Lectin blotting: Proteins extracted from the olfactory organ of lungfish were analyzed by blotting with 6 lectins: PNA, SJA, Jaca, ECL, LEL and BSL-I. The first four, PNA, SJA, Jaca and ECL, were used, because they almost exclusively labeled the glandular epithelium in the olfactory organ. On the other hand, the last two, LEL and BSL-I, were chosen, because they intensely labeled the glandular epithelium and some other regions in the olfactory organ. PNA detected 4 major bands at 120, 100, 75 and $70 \mathrm{kDa}$ (Fig. 4). SJA detected 6 major bands at $>250,120,100,80,75$ and 70 $\mathrm{kDa}$ (Fig. 4). Jaca detected 3 major bands at 200, 120 and 70 $\mathrm{kDa}$ (Fig. 4). ECL detected a single band at $80 \mathrm{kDa}$ (Fig. 5). LEL detected 8 major bands at 120, 100, 80, 75, 70, 60, 40 and $25 \mathrm{kDa}$ (Fig. 5). BSL-I detected 4 bands at 120, 80, 75 and $70 \mathrm{kDa}$ (Fig. 5). Staining intensities of most bands were decreased after pre-incubation of lectins with the appropriate competing sugars (data not shown).

\section{DISCUSSION}

In the olfactory organ of lungfish, the recess epithelium corresponding to the VNO of tetrapods is equipped with the associated glands, while the lamellar OE corresponding to the OE of ordinary fish is not. The glandular cells in the olfactory organ of lungfish showed ultrastructural characteristics similar to those in the Jacobson's glands of the Japanese reddish frog [27]; they contained numerous electron-dense granules and well-developed rER in their cytoplasm. In general, the mucous cells possess electron-lucent granules and compressed nuclei, while the serous cells possess electrondense granules, abundant rER and round nuclei [28]. Thus, the cells constituting the associated glands in the olfactory 


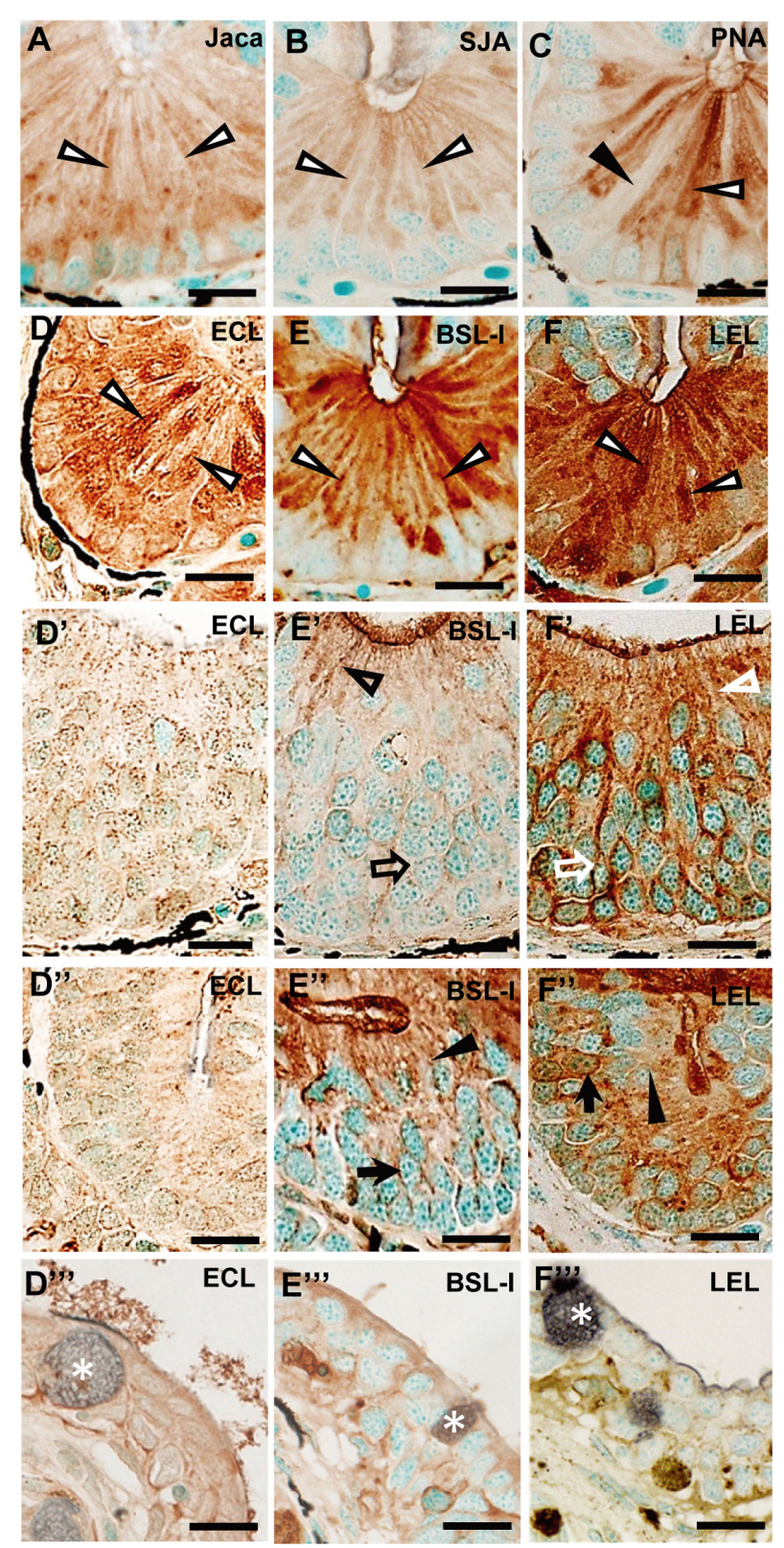

Fig. 3. Lectin histochemistry in the olfactory organ of lungfish. High magnification views of the glandular epithelium (A-F), the lamellar OE (D'-F'), the recess epithelium (D"-F") and the respiratory epithelium (D"'-F"'). Punctate staining for the six lectins are observed in the cytoplasm of the glandular cells (white arrowheads in A-F). Some glandular cells are stained with PNA (white arrowhead in C), while others are not (black arrowhead in C). (D'-D'”) ECL does not stain the lamellar OE, the recess epithelium and the respiratory epithelium. (E') BSL-I weakly stains the cytoplasm of supporting cells (open arrowhead), but not the olfactory receptor cells (open arrow) in the lamellar OE. (E") BSL-I moderately stains the receptor cells (black arrow) and supporting cells (black arrowhead) in the recess epithelium. (F') LEL moderately stains the supporting cells (open arrowhead) and intensely stains the olfactory receptor cells (open arrow) in the lamellar OE. (F") LEL moderately stains the supporting cells (black arrowhead) and intensely stains the receptor cells (black arrow) in the recess epithelium. (E"' and F"') BSL-I and LEL do not stain the respiratory epithelium. The goblet cells (gray color, asterisks in D"'-F"') are stained with methyl green for counter stain, but not stained with these lectins. Scale bars $=25 \mu \mathrm{m}$.

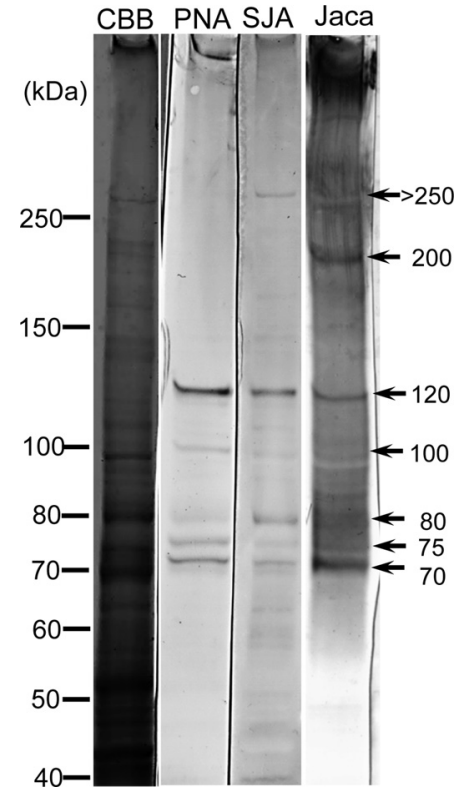

Fig. 4. Lectin blotting for PNA, SJA and Jaca in the olfactory organ of lungfish. The molecular weights $(\mathrm{kDa})$ of marker proteins are indicated on the left. The left lane is the protein extracted from the olfactory organ stained with Coomassie Brilliant Blue (CBB). PNA detects 4 major bands at 120,100, 75 and $70 \mathrm{kDa}$. SJA detects 6 major bands at $>250,120,100,80,75$ and $70 \mathrm{kDa}$. Jaca detects 3 major bands at 200, 120 and $70 \mathrm{kDa}$. Arrows on the right indicate all major bands which are detected by these lectins.

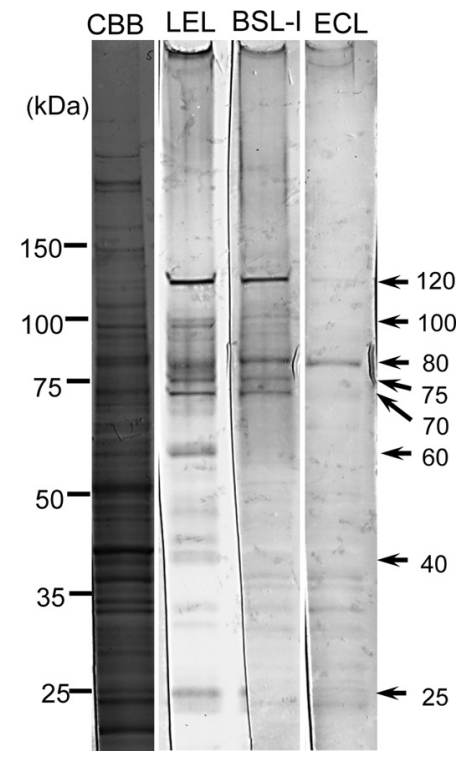

Fig. 5. Lectin blotting for LEL, BSL-I and ECL in the olfactory organ of lungfish. The molecular weights $(\mathrm{kDa})$ of marker proteins are indicated on the left. The left lane is the protein extracted from the olfactory organ stained with CBB. LEL detects 8 major bands at $120,100,80,75,70,60,40$ and $25 \mathrm{kDa}$. BSL-I detects 4 major bands at 120, 80, 75 and $70 \mathrm{kDa}$. ECL detects a single major band at $80 \mathrm{kDa}$. Arrows on the right indicate all major bands which are detected by these lectins. 
organ of lungfish are considered to be the serous cells and mainly secrete proteins. In addition, secretory granules were likely to be discharged from the apical membrane of the glandular cells. These data suggest that the glandular cells actively produce and secrete proteins to cover the surface of neighboring recess epithelium.

The secretory products from the associated glands in the olfactory organs cover the surface of sensory epithelia and play important roles in the interaction between olfactory receptors and odorant molecules $[8,9,12,13,20]$. The ultrastructure and histochemical properties of secretory granules in the glandular cells are different between the Bowman's glands and the Jacobson's glands [1, 3, 6, 15, 27]. In addition, the supporting cells in the olfactory sensory epithelium of non-mammalian vertebrates have secretory granules containing secretory products which are supposed to play certain roles in the olfaction [8]. The ultrastructural characteristics of secretory granules in the supporting cells are also different between individual sensory epithelia, as seen in clawed frog [11]. Also in lungfish, the proteins present on the surface of the recess epithelium might influence the olfactory perception and are supposed to be provided by the glandular cell and/or the supporting cells in the recess epithelium. Thus, the olfactory organ of lungfish was analyzed by lectin histochemistry using 16 lectins to examine whether the properties of the secretory granules contained in different types of secretory cells are different from each other.

Seven lectins (WGA, STL, BSL-I, VVA, SJA, UEA-I and PSA) stained the cytoplasm of supporting cells in the lamellar OE at different intensity from those in the recess epithelium, suggesting that the properties of secretory granules in the supporting cells were different between these two epithelia. These data are correlated with our previous study that revealed the ultrastructural differences of the secretory granules between the supporting cells in the lamellar OE and those in the recess epithelium [19]. Based on the ultrastructural and immunohistochemical data on the receptor cells, the lamellar $\mathrm{OE}$ and the recess epithelium are considered to be the sensory epithelia engaging in the different olfactory perception from each other $[10,19]$. The differences in the properties of secretory granules contained in the supporting cells suggest the functional difference between these two epithelia. In other vertebrates, binding patterns for lectins in the cytoplasm of supporting cells are also different between the OE and the VNO [2, 7, 14, 23]. These differences have been considered to be related to the differences in the olfactory function between the OE and the VNO.

Fourteen of the lectins utilized (except for WGA and VVA) stained the glandular cells and the supporting cells in the recess epithelium at different intensity, suggesting that properties of secretory granules contained in these cells are different from each other. These data suggest that the glandular cells and the supporting cells in the recess epithelium secrete proteins with different properties and have distinct effects on the function of the recess epithelium.

Punctate staining for the 16 lectins was observed in the cytoplasm of glandular cells in the associated glands. This staining pattern suggests that these lectins bind to glyco- conjugates contained in the secretory granules of glandular cells. Four lectins (SJA, Jaca, PNA and ECL) stained the cytoplasm of glandular cells, whereas they did not stain or only weakly stained any other part of the nasal epithelium (the lamellar OE, the recess epithelium and the respiratory epithelium). Because these lectins exclusively labeled the secretory granules of glandular cells, they were used to analyze the proteins extracted from the olfactory organs of lungfish and to detect different patterns of protein bands by the lectin blotting. Each lectin detected multiple bands of proteins containing sugar residues recognized by respective lectins, as in the olfactory organ of clawed frog [25]. Unfortunately, comparison of proteins contained in the olfactory organ of lungfish and frog is not possible, because molecular weights of proteins detected by lectins in the frog were not fully indicated. In the olfactory organ of lungfish, the number of protein bands detected by lectins differed depending on the carbohydrate specificity of each lectin. Although PNA and Jaca bind specifically to the same sugar residues containing galactosyl- $\beta$-GalNAc, they detected different numbers of protein bands, because they do not have an absolute specificity and therefore can bind with different affinities to a number of similar carbohydrates. Individual bands are considered to represent the glycoproteins contained in the secretory granules of the glandular cells. Seven bands $(>250$, $200,120,100,80,75$ and $70 \mathrm{kDa}$ ) were detected by at least one of these lectins, and 5 of them $(120,100,80,75$ and $70 \mathrm{kDa}$ ) were detected by more than two lectins. These data suggest that secretory granules in the glandular cells contain at least 7 types of glycoproteins with different expression patterns of sugar residues.

LEL intensely stained the glandular cells, the lamellar OE and the recess epithelium, and detected 8 bands by lectin blotting. Among them, 5 bands $(120,100,80,75$ and 70 $\mathrm{kDa}$ ) were also detected by the lectins specifically labeling the glandular cells as described above. BSL-I intensely stained the glandular cells and the recess epithelium, but not the lamellar OE. This lectin detected 4 bands (120, 80, 75 and $70 \mathrm{kDa}$ ) by lectin blotting, which were also detected by the lectins specifically labeling the glandular cells. LEL and BSL-I intensely stained the cytoplasm of glandular cells, and detected several bands at the same molecular weight as the lectins specifically labeling the glandular cells. These results strongly support the possibility that some of the protein bands detected by these lectins are derived from glycoproteins contained in the secretory granules of the glandular cells.

In general, the olfactory organs of fish are not considered to need associated glands, because they can always contact with the surrounding fluid in which they live [8]. However, the olfactory organ of lungfish is equipped with the associated glands located only in the recesses [19]. It suggests that secretory products from the associated glands play important roles in the olfactory perception of the recess epithelium. The present study revealed the lectin binding patterns in the secretory granules of the glandular cells and the molecular weights of multiple glycoproteins with different carbohydrate moieties contained in the secretory granules of the glandular cells. It remains unknown how these glycoproteins 
act on the recess epithelium. However, data obtained in this study could provide a basis for further elucidating the function of the secretory products from this associated gland in the future.

\section{REFERENCES}

1. Carmanchahi, P. D., Aldana Marcos, H. J., Ferrari, C. C. and Affanni, J. M. 1999. The vomeronasal organ of the South American armadillo Chaetophractus villosus (Xenarthra, Mammalia): anatomy, histology and ultrastructure. J. Anat. 195: 587-604. [Medline] [CrossRef]

2. Carmanchahi, P. D., Ferrari, C. C., Marcos, H. J., Affanni, J. M., Sonez, C. A. and Paz, D. A. 2000. Characterisation of glycoconjugate sugar residues in the vomeronasal organ of the armadillo Chaetophractus villosus (Mammalia, Xenarthra). J. Anat. 196: 357-370. [Medline] [CrossRef]

3. Cuschieri, A. and Bannister, L. H. 1975. The development of the olfactory mucosa in the mouse: electron microscopy. J. Anat. 119: 471-498. [Medline]

4. Døving, K. B. and Trotier, D. 1998. Structure and function of the vomeronasal organ. J. Exp. Biol. 201: 2913-2925. [Medline]

5. Endo, D., Yamamoto, Y., Nakamuta, N. and Taniguchi, K. 2011. Developmental changes in lectin-binding patterns of three nasal sensory epithelia in Xenopus laevis. Anat. Rec. 294: 839-846. [Medline] [CrossRef]

6. Ferrari, C. C., Aldana-Marcos, H. J., Carmanchahi, P. D. and Affanni, J. M. 1998. Olfactory mucosa of the South American armadillo Chaetophractus villosus: an ultrastructural study. Anat. Rec. 252: 325-339. [Medline] [CrossRef]

7. Ferrari, C. C., Carmanchahi, P. D., Aldana-Marcos, H. J., Mugnaini, M. T., Affanni, J. M. and Paz, D. A. 1999. Identification and localisation of glycoconjugates in the olfactory mucosa of the armadillo Chaetophractus villosus. J. Anat. 194: 395-405. [Medline] [CrossRef]

8. Getchell, M. L. and Getchell, T. V. 1992. Fine structural aspects of secretion and extrinsic innervation in the olfactory mucosa. Microsc. Res. Tech. 23: 111-127. [Medline] [CrossRef]

9. Getchell, T. V., Margolis, F. L. and Getchell, M. L. 1984. Perireceptor and receptor events in vertebrate olfaction. Prog. Neurobiol. 23: 317-345. [Medline] [CrossRef]

10. González, A., Morona, R., López, J. M., Moreno, N. and Northcutt, R. G. 2010. Lungfishes, like tetrapods, possess a vomeronasal system. Front. Neuroanat. 4: 130. [Medline]

11. Hansen, A., Reiss, J. O., Gentry, C. L. and Burd, G. D. 1998. Ultrastructure of the olfactory organ in the clawed frog, Xenopus laevis, during larval development and metamorphosis. J. Comp. Neurol. 398: 273-288. [Medline] [CrossRef]

12. Iwasa, T., Mandula, G., Urano, K., Takahashi, T., Sawada, K., Okano, K. and Nakamura, T. 2008. Lipocalin-family proteins expressed in the Bowman's gland of the newt olfactory organ. Jpn. J. Taste Smell Res. 15: 211-220 (in Japanese).

13. Khew-Goodall, Y., Grillo, M., Getchell, M. L., Danho, W., Getchell, T. V. and Margolis, F. L. 1991. Vomeromodulin, a putative pheromone transporter: cloning, characterization, and cellular localization of a novel glycoprotein of lateral nasal gland.
FASEB J. 5: 2976-2982. [Medline]

14. Kondoh, D., Yamamoto, Y., Nakamuta, N., Taniguchi, K. and Taniguchi, K. 2010. Lectin histochemical studies on the olfactory epithelium and vomeronasal organ in the Japanese striped snake, Elaphe quadrivirgata. J. Morphol. 271: 1197-1203. [Medline] [CrossRef]

15. Mendoza, A. S. 1986. The mouse vomeronasal glands: a light and electron microscopical study. Chem. Senses 11: 541-555. [CrossRef]

16. Nakajima, T., Shiratori, K., Ogawa, K., Tanioka, Y. and Taniguchi, K. 1998. Lectin-binding patterns in the olfactory epithelium and vomeronasal organ of the common marmoset. J. Vet. Med. Sci. 60: 1005-1011. [Medline] [CrossRef]

17. Nakamuta, N., Yokoyama, N., Yamamoto, Y., Taniguchi, K. and Taniguchi, K. 2010. Lectin histochemical analysis of the olfactory bulbs in the barfin flounder (Verasper moseri). Anat. Histol. Embryol. 39: 67-73. [Medline] [CrossRef]

18. Nakamuta, S., Nakamuta, N. and Taniguchi, K. 2011. Distinct axonal projections from two types of olfactory receptor neurons in the middle chamber epithelium of Xenopus laevis. Cell Tissue Res. 346: 27-33. [Medline] [CrossRef]

19. Nakamuta, S., Nakamuta, N., Taniguchi, K. and Taniguchi, K. 2012. Histological and ultrastructural characteristics of the primordial vomeronasal organ in lungfish. Anat. Rec. 295: 481-491. [Medline] [CrossRef]

20. Pelosi, P. 1996. Perireceptor events in olfaction. J. Neurobiol. 30: 3-19. [Medline] [CrossRef]

21. Riddle, D. R., Wong, L. D. and Oakley, B. 1993. Lectin identification of olfactory receptor neuron subclasses with segregated central projections. J. Neurosci. 13: 3018-3033. [Medline]

22. Roth, J. 2011. Lectins for histochemical demonstration of glycans. Histochem. Cell Biol. 136: 117-130. [Medline] [CrossRef]

23. Saito, S., Matsui, T., Kobayashi, N., Wakisaka, H., Mominoki, K., Matsuda, S. and Taniguchi, K. 2003. Lectin histochemical study on the olfactory organ of the newt, Cynops pyrrhogaster, revealed heterogeneous mucous environments in a single nasal cavity. Anat. Embryol. (Berl) 206: 349-356. [Medline]

24. Spicer, S. S. and Schulte, B. A. 1992. Diversity of cell glycoconjugates shown histochemically: a perspective. J. Histochem. Cytochem. 40: 1-38. [Medline] [CrossRef]

25. Suzuki, K., Taniguchi, K. and Syuto, B. 1999. Characterization of olfactory receptor organs in Xenopus laevis Daudin. Anat. Rec. 255: 420-427. [Medline] [CrossRef]

26. Takami, S., Getchell, M. L. and Getchell, T. V. 1994. Lectin histochemical localization of galactose, N-acetylgalactosamine, and $\mathrm{N}$-acetylglucosamine in glycoconjugates of the rat vomeronasal organ, with comparison to the olfactory and septal mucosae. Cell Tissue Res. 277: 211-230. [Medline] [CrossRef]

27. Taniguchi, K., Toshima, Y., Saito, T. R. and Taniguchi, K. 1996. Development of the Bowman's and Jacobson's glands in the Japanese reddish frog, Rana japonica. J. Vet. Med. Sci. 58: 17-22. [Medline] [CrossRef]

28. Wolff, M. S., Mirels, L., Lagner, J. and Hand, A. R. 2002. Development of the rat sublingual gland: a light and electron microscopic immunocytochemical study. Anat. Rec. 266: 30-42. [Medline] [CrossRef] 